\title{
Architectural Notices, Relating to the Church of Gillingham, Norfolk
}

\section{John Louis Petit}

To cite this article: John Louis Petit (1850) Architectural Notices, Relating to the Church of Gillingham, Norfolk, Archaeological Journal, 7:1, 142-146, DOI: 10.1080/00665983.1850.10850777

To link to this article: http://dx.doi.org/10.1080/00665983.1850.10850777

$$
\text { 册 Published online: } 06 \text { Dec } 2014 .
$$

Submit your article to this journal $\sqsubset \pi$

Q View related articles $₫$ 


\section{ARCHITECTURAL NOTICES, RELATING TO THE CHURCH OF GILLINGHAM, NORFOLK.}

THE interesting series of Architectural Illustrations, accompanied by a description of Gillingham Church, in Norfolk, here submitted to the Archaeological Institute, have been prepared by Mr. T. Hill, whom I requested to undertake them, during his temporary residence in the neighbourhood. The church is a fine specimen of pure Norman, of an early rather than a late period; apparently belonging to the reign of Henry I., and in its plan it is, I think, nearly unique. It is divided lengthwise into five parts : a western compartment, a tower, a nave, a chancel, and an apse. The western part is more than a mere porch, as it opens into the tower, not by a door, but an arch, similar to that between the tower and the eastern part of the church. The tower, being narrower than the nave and this compartment, is supported by arches to the north and south, as though it were the centre of a cross church. There is an arch between the nave and chancel, also between the chancel and the apse. A modern south transept is added, and some lancet windows, probably later than the Norman work, appear in the chancel. The mouldings, in general, are very bold and effective. Gillingham is about a mile from Beccles, on the Yarmouth road.

JOHN LOUIS PETIT.

P.S. Rowington Church, in Warwickshire, affords another instance of a tower rising from the centre of the nave. It is of a later date and style altogether.

\section{GILLINGHAM CHURCH, CLAVERING HUNDRED, NORFOLK.}

Gillingham is called in the Domesday Survey "Kildincham," and it appears from that document, that this Manor was held by Guerd; King Harold's brother, Stigand, Archbishop of Canterbury, having the soc. The church property is mentioned as consisting entirely of meadow land. Guerd was deprived of it at the Conquest, and it passed into the hands of the King. In King Edward I.'s reign, Gillingham seems to have been held by two separate parties, out of which two fees, came two lordships with two churches. 


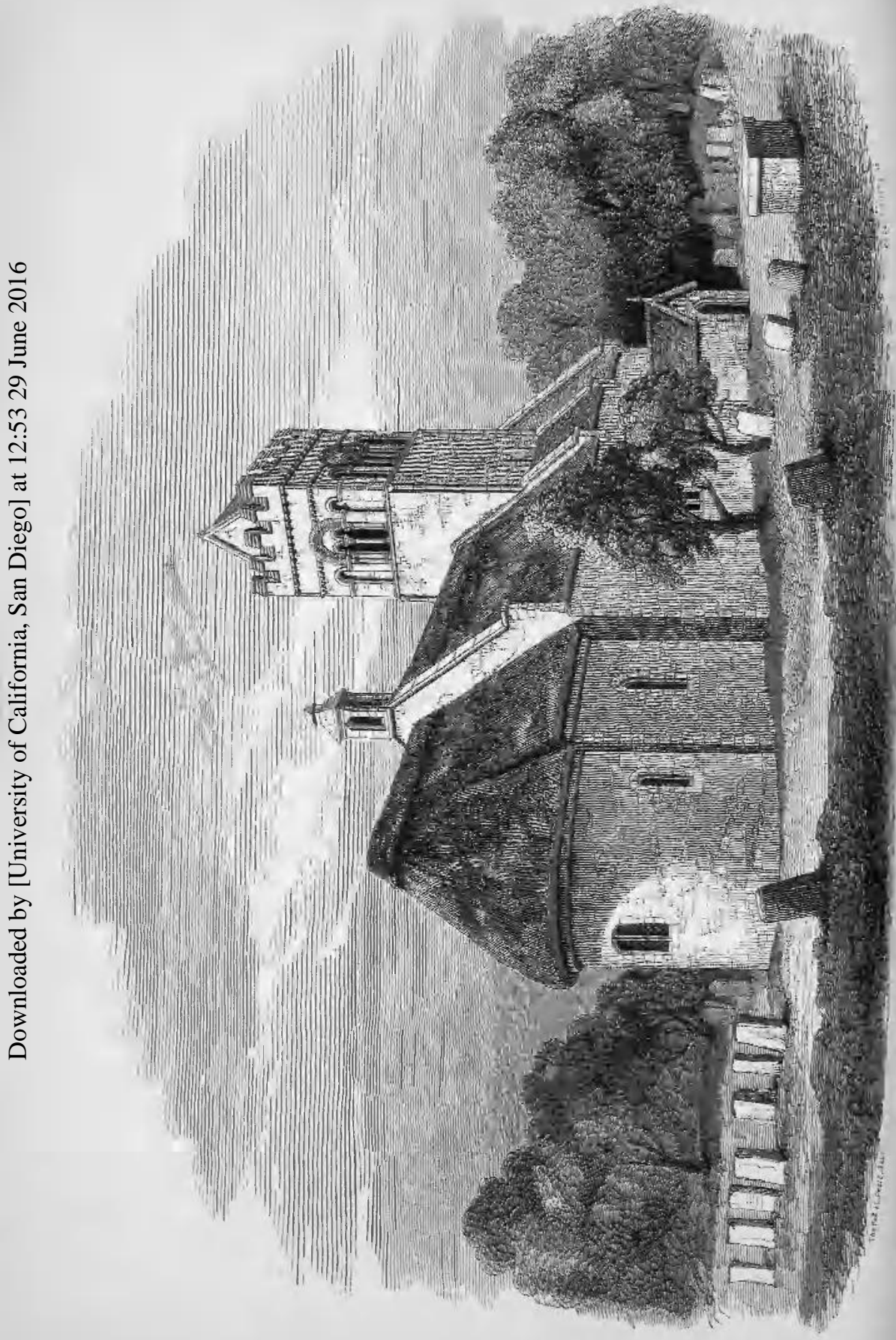



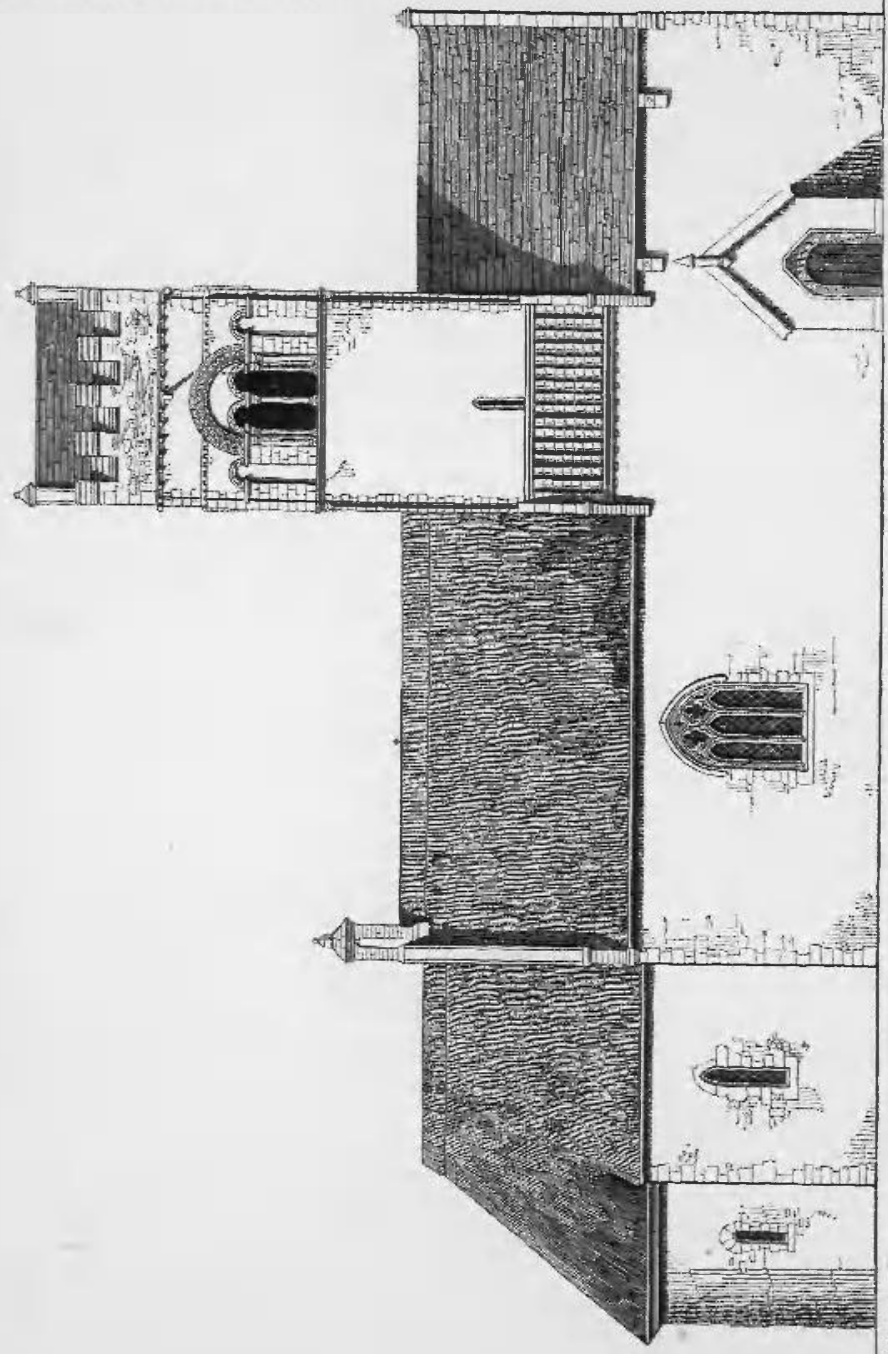


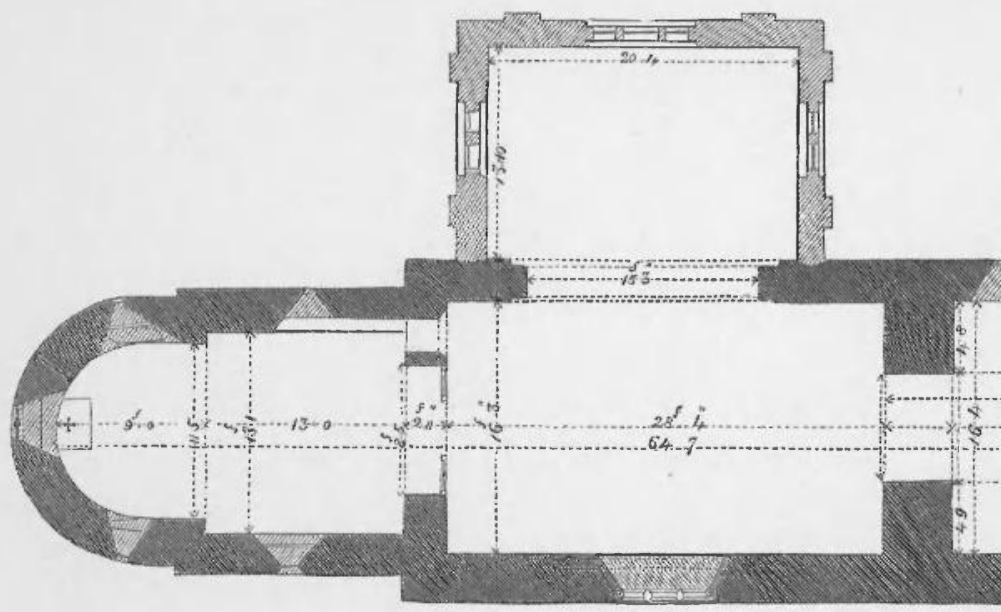

(H)

Ground Plan, St. Mary's, Gillinghham, Norfoilk. 
ST. MARY'S, GILLINGHAM, NORFOLK.

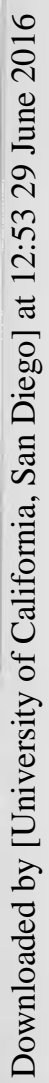

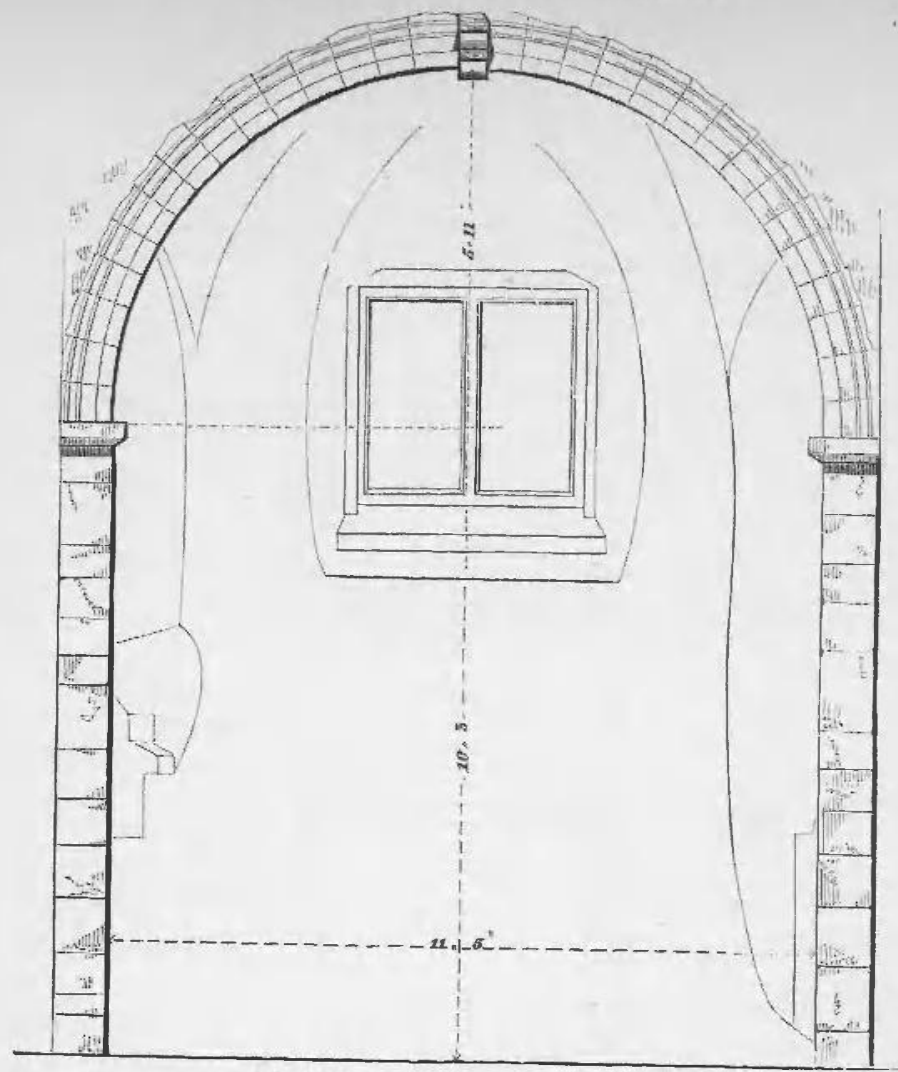

Weat Elevation of Arch into APSE.

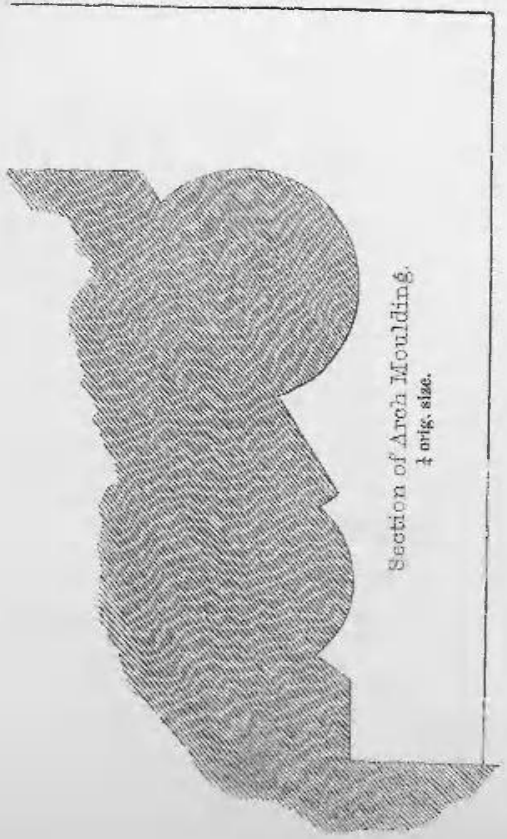

Section of Abacus torig. size 
ST. MARY'S, GILLINGHAM NORFOLK.

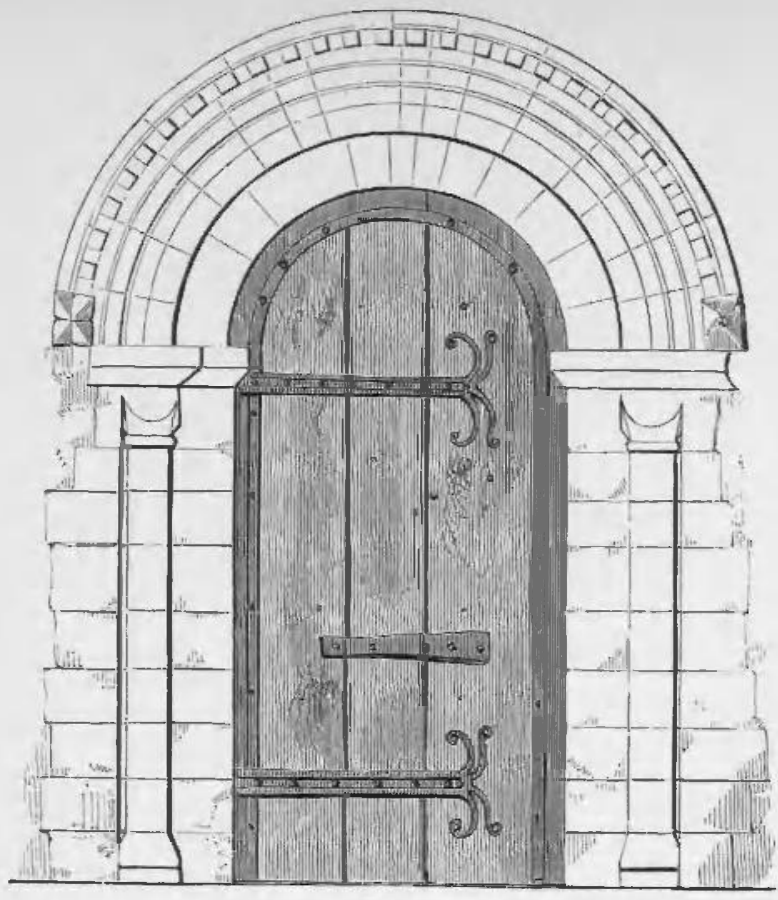

Elevation of Western Doorway.
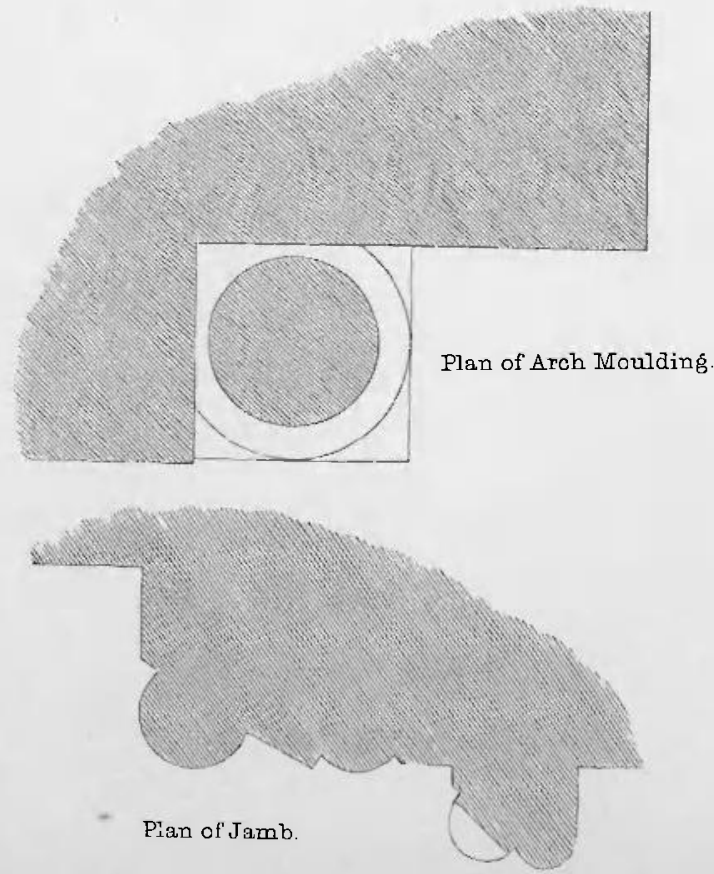
ST, MARY'S, GILLINGHAM, NORFOLK.

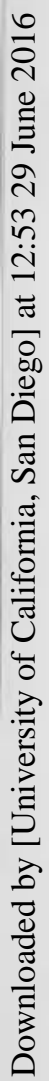

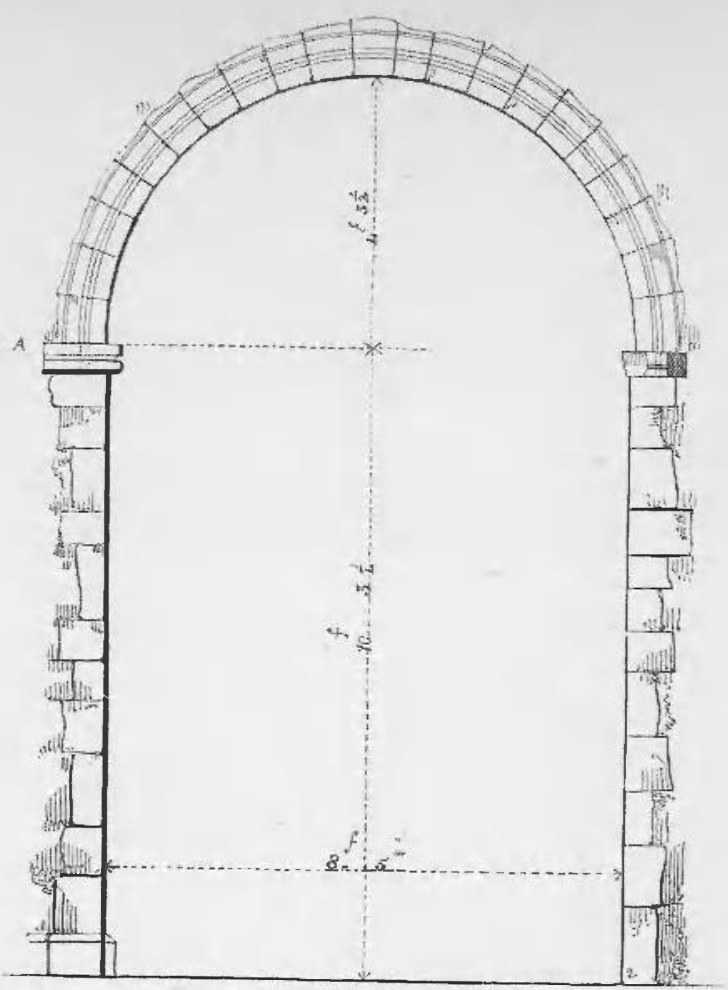

West Flevation of Chancel Arch.

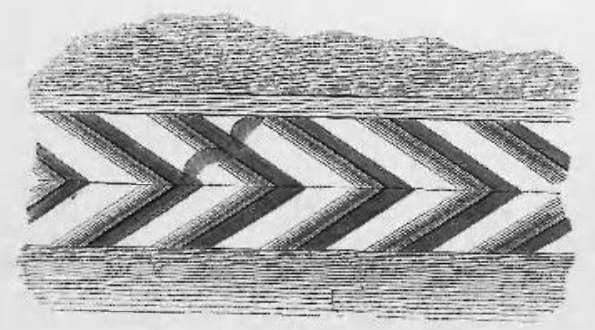

Soffit of Abacus.

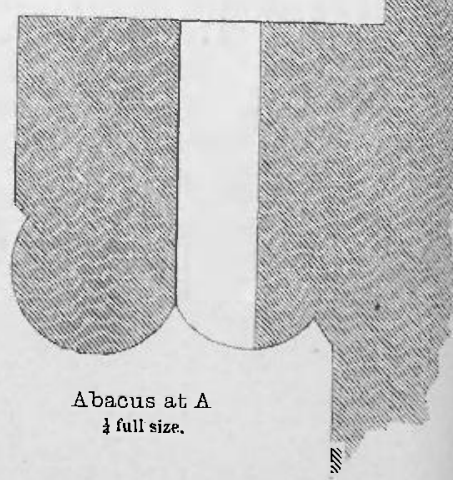


ST. MARY'S, GILLINGHAM, NORFOLK,

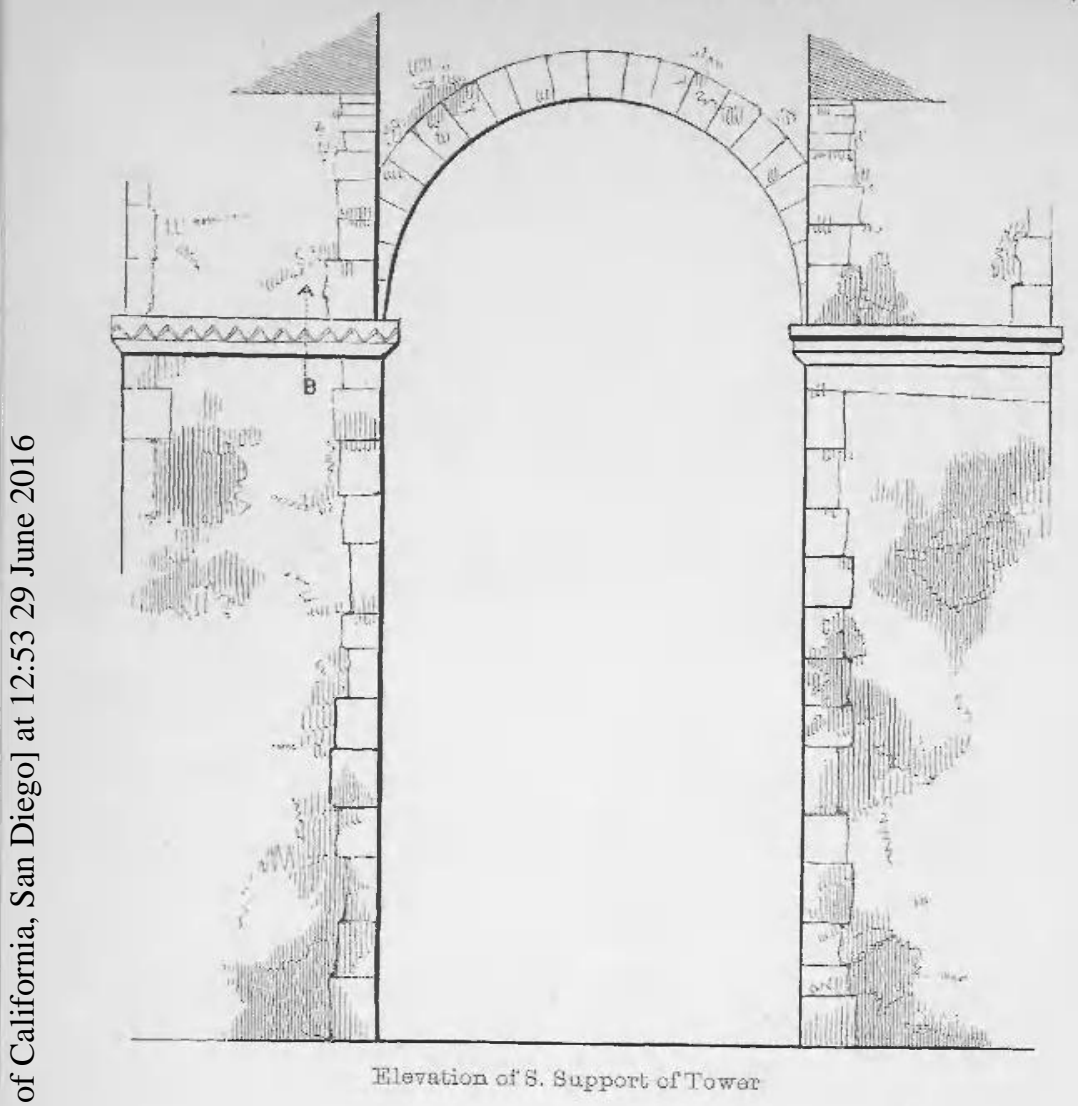

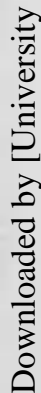
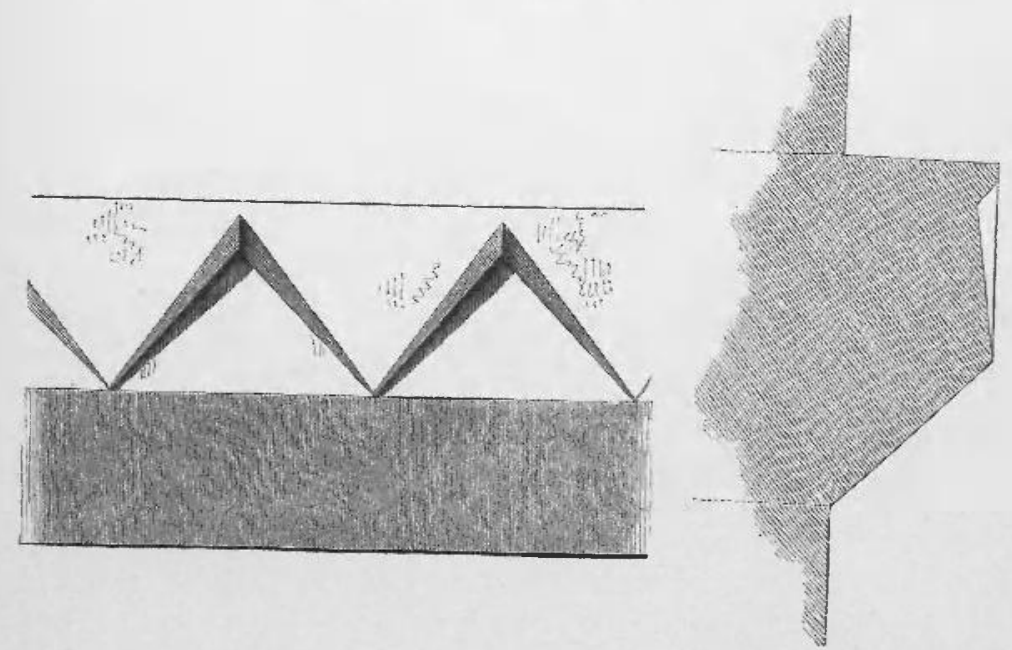

Elevation of Abacus.

and

Section at A. B 
ST. MARY'S, GILLINGHAM, NORFOLK.

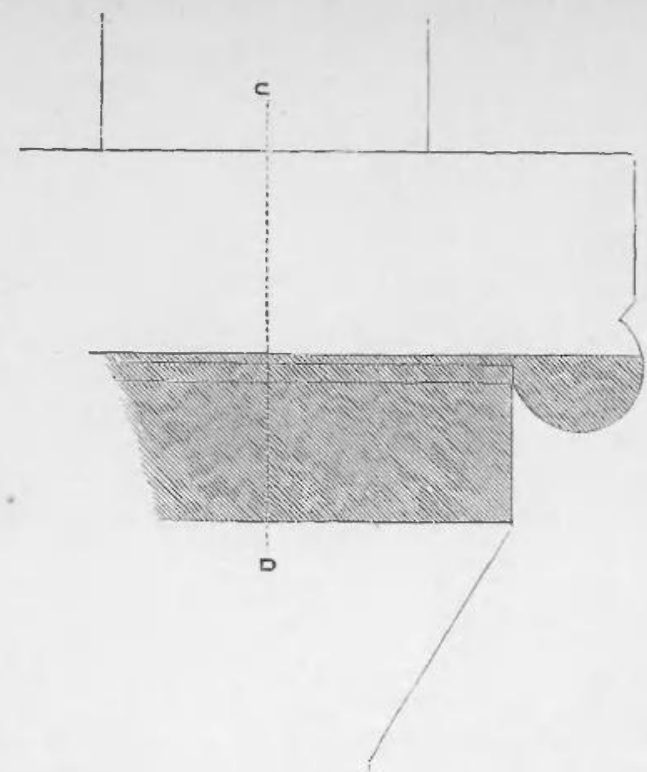

Elevation of Impost Mouldinś, S W. anģle of Tower

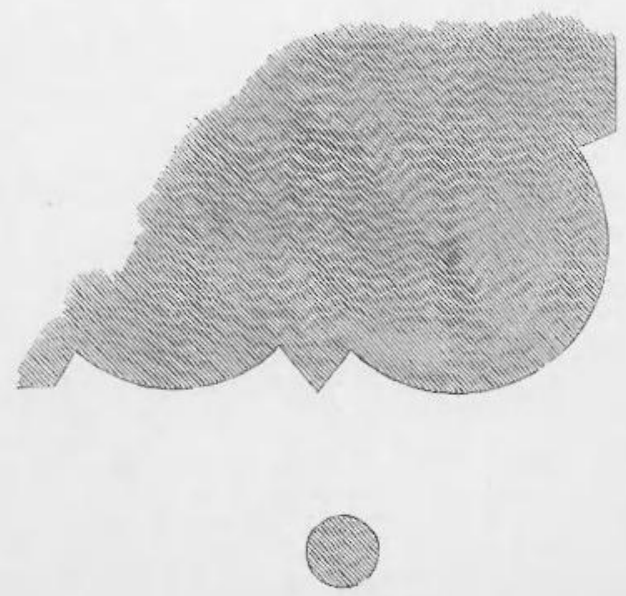

Plan of Chancel Arch, showing the perforation. 
ST. MARY'S, GILLINGBAM, NORFOLK.

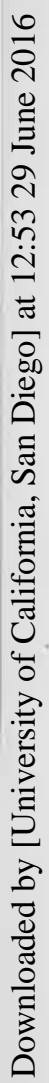
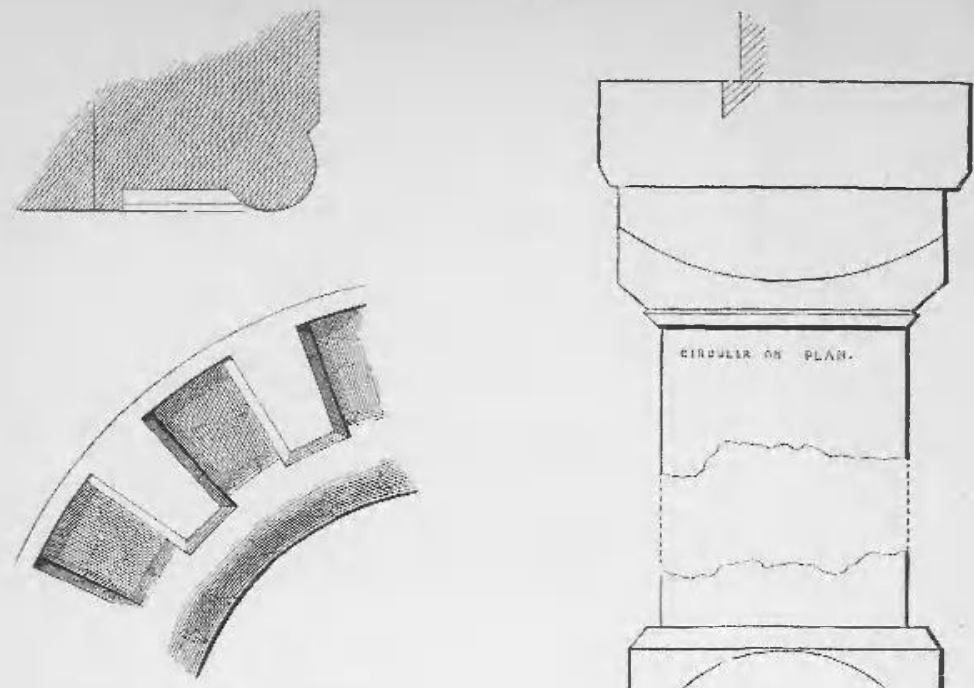

Details of S. Side of Tower

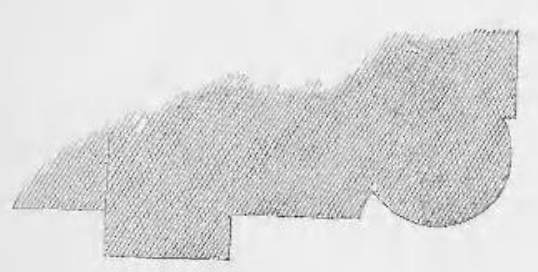

Elevation of Centre Column, Beltry.

\section{Section}

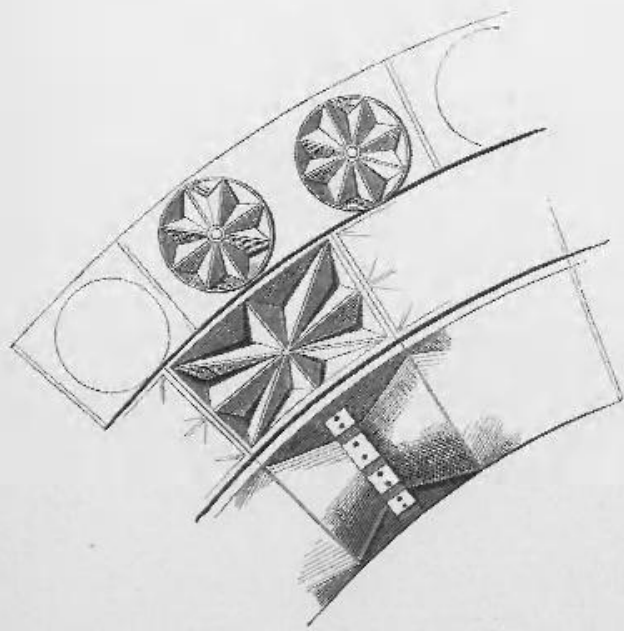

Eievation at A. B . Belfry Window

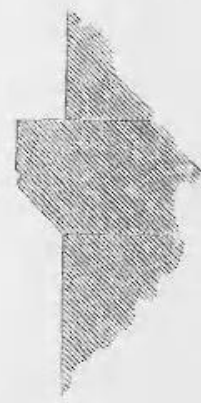

Section of Abacus

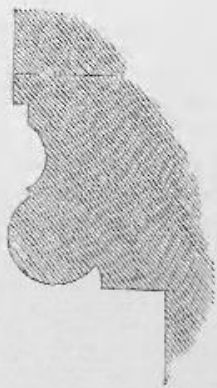

Section of Side Arch at C.D 
ST. MARY'S, GILLINGHAM, NORFOLK.

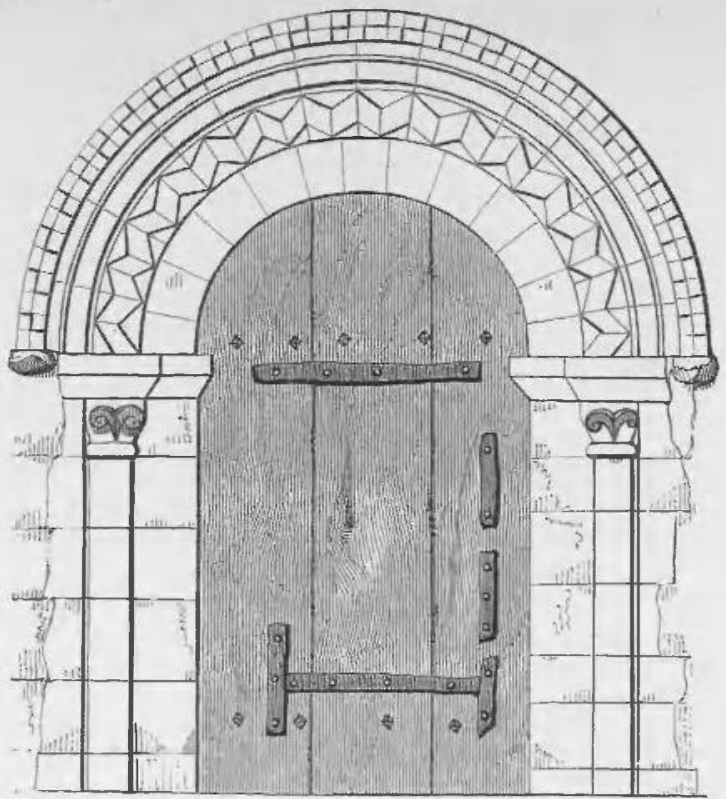

North Doorway.

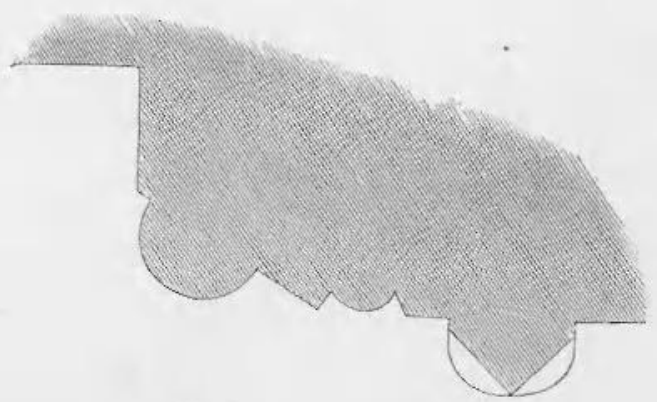

Section of Arch Mouldins.

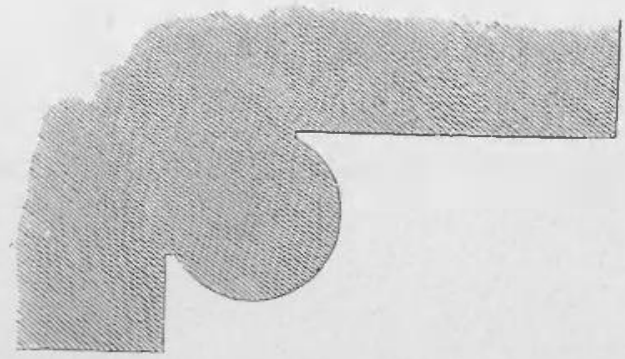

Section of Jamb. 
ST. MARY'S CHURCH, GILLINGHAM NORFOLK.

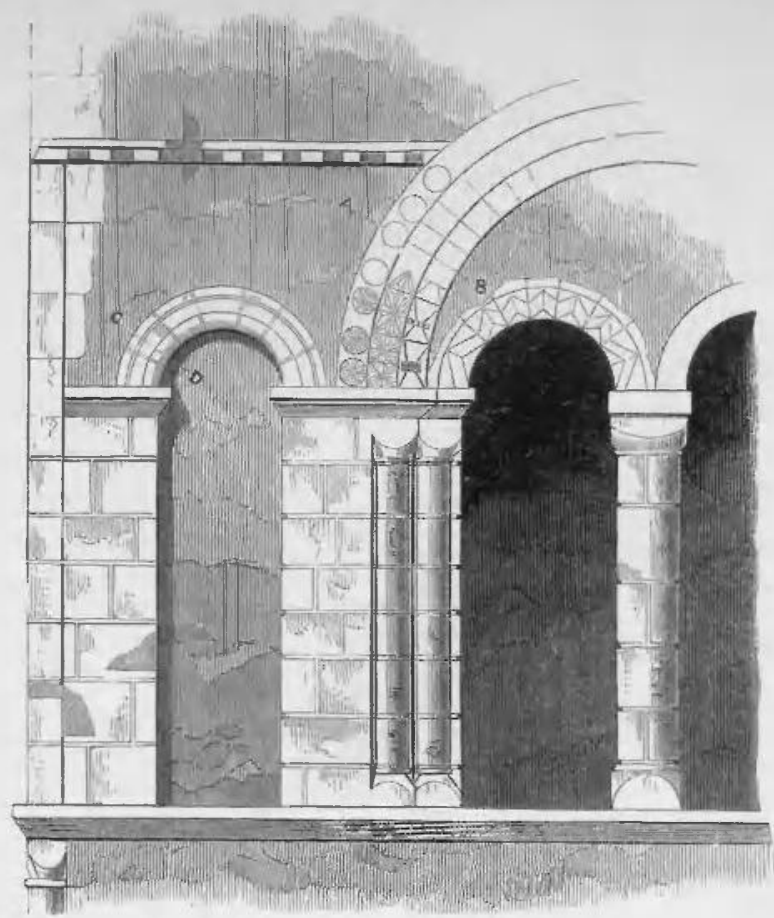

Elevation of Belfry Window

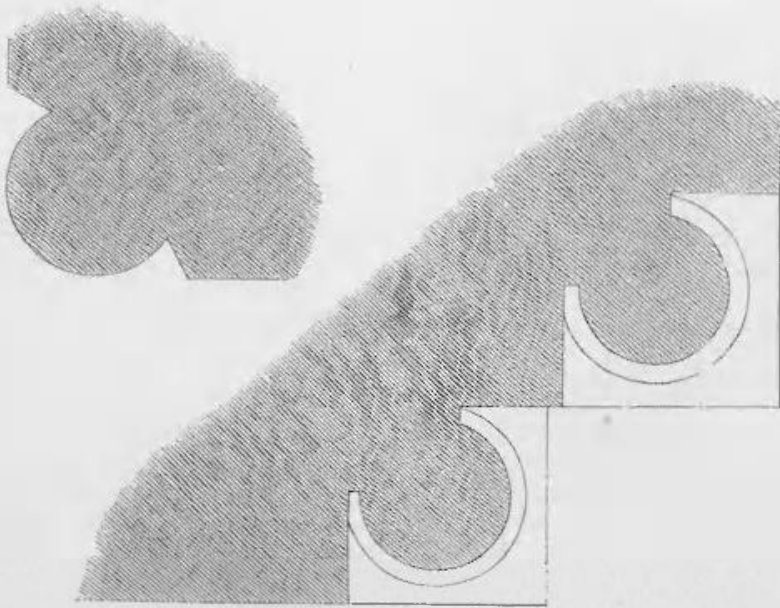

Plan of Jambs of Belfry openins 
ST. MARY'S, GILLINGHAM, NORFOLK.

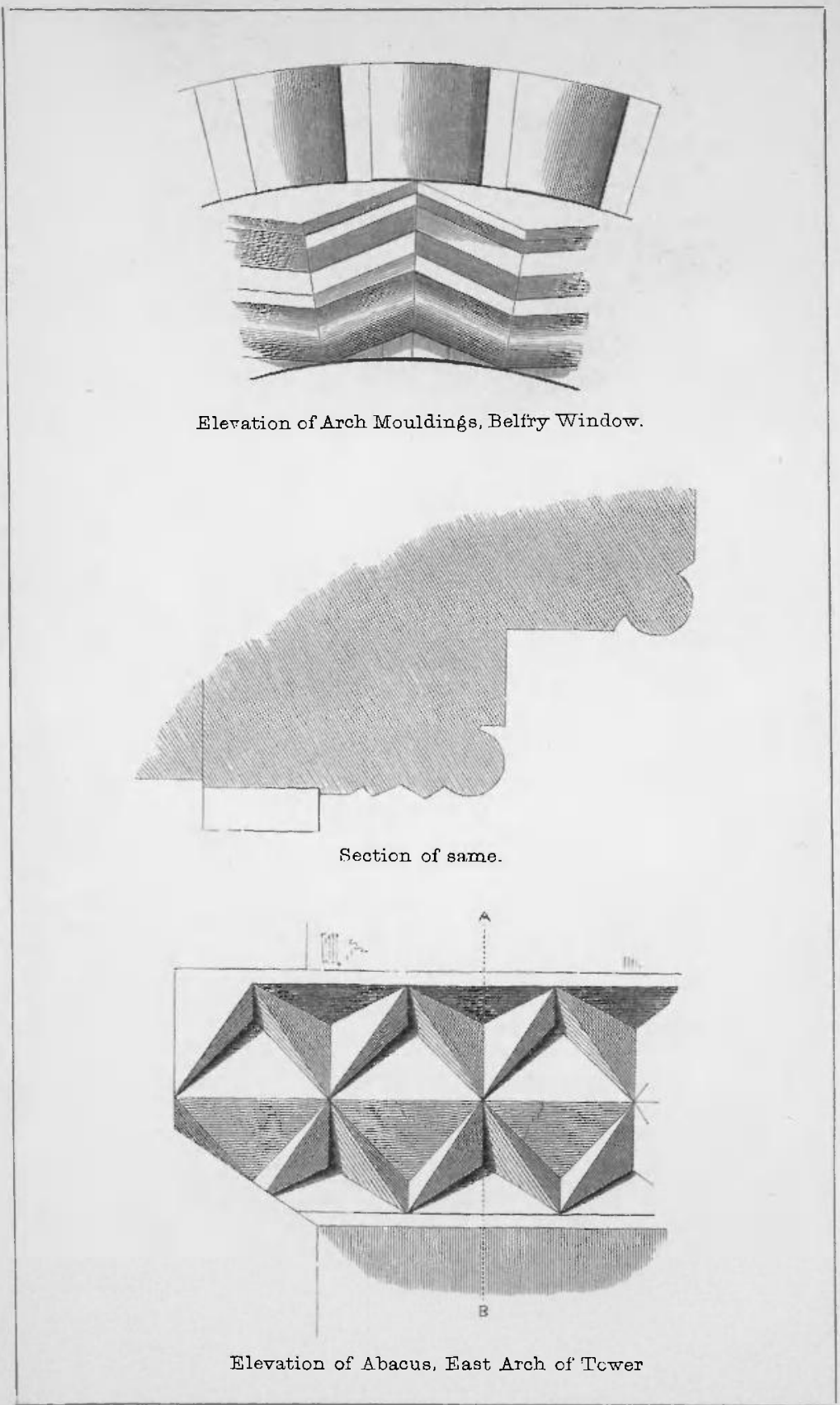

T. Hill, Areh. 
The first mention of Gillingham All Saints is in the reign of Stephen, when that king granted the same to Hugh de Bigot on his being created Earl of Norfolk; it descended to

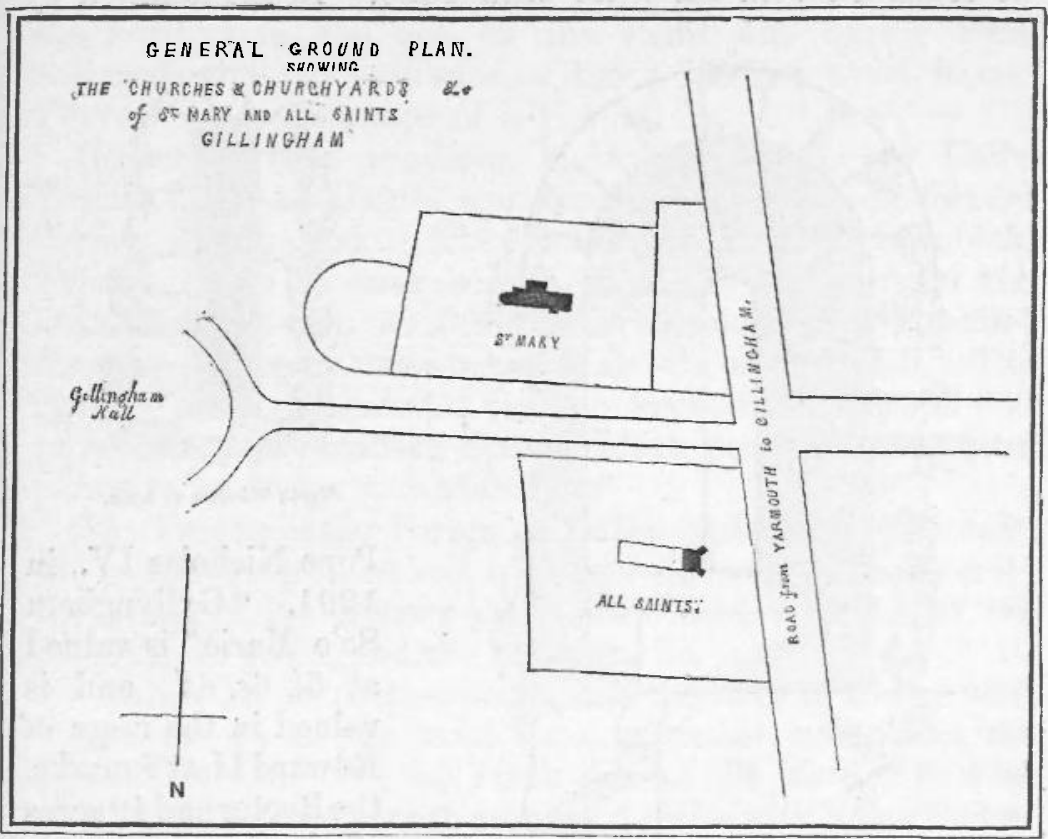

Ground Plan of St. Mary's and All Saints'.

Edward I. by gift, then to the Mowbrays, Dukes of Norfolk. (In this reign the Rector had 34 acres, but no manse, and the living was valued at 9 marks, Peter-pence $12 d$. carvage $3 d$.) It then passed to the Howards. The churches of St. Andrew at Windeston, and St. Andrew at Wyndell, were consolidated with Gillingham All Saints; the former on the 9th day of February, 1440, and the latter the 20th day of July, 1449 : after this consolidation, All Saints was valued at $6 l .8 s .9 d$. in Henry VIII.'s reign. It was forfeited to the Crown in Queen Elizabeth's reign, and granted by James I. to Henry Howard, Earl of Northampton ; then it passed to the Earl of Surrey, and from him to Sir Nicholas Bacon, Bart. The value before the demolition of the church, in 1748, was 5l. $6 s .8 d$. The church consisted of two aisles and a chancel covered with thatch, and a square tower with three bells. The tower is the only part standing; the other parts were pulled down in 1748, and the flint used to mend the roads. voL. vil. 
The first mention of Gillingham St. Mary is, that Geffrey de Ponte, or Pount, had the patronage in the 55th of Henry III., but when granted by the Crown does not appear; it remained with his heirs until 1320 . In the taxation by

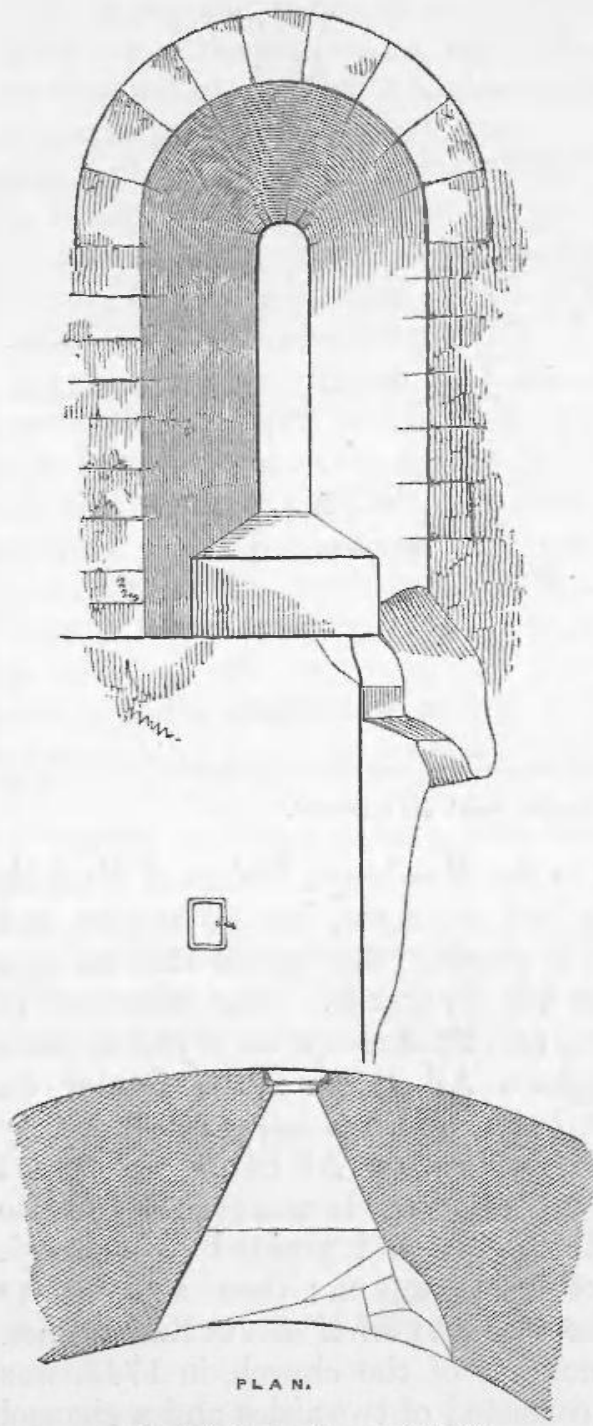

North Window in Apse. Interior view.

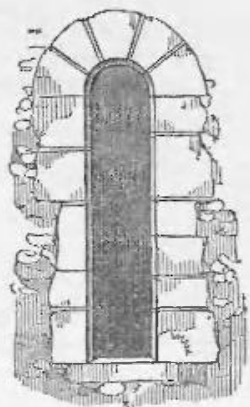

North Window of Apse.

Pope Nicholas IV., in 1291, "Gyllyngham Sc'e Marie" is valued at $5 l .6 s .8 d$. , and is valued in the reign of Edward II. at 8 marks, the Rector had 40 acres of land, no manse, Peter-pence $8 d$. ob., carvage $3 d$., "Jeffrey de Ponte" patron. In 1320, Bartholomew Bateman was inducted to this living, and it was passed by fine to John Everard in the 28th of Henry VIII., valued in his reign at 5l. 14s. $0 d$. From John Everard itpassed to the Bacons, in the reign of James I.

St. Mary belonged to the manor of which

Guerd was deprived at the Conquest.

All Saints and St. Mary were consolidated in $\mathbf{1 7 4 8 .}$ 
The following observations supply a concise description of the interior and exterior of this remarkable church of St. Mary's, Gillingham.

(Apse.) The only remaining perfect window is that on the north side, the one on the south side having been enlarged, and the east window has a modern wood frame. There is no appearance of a piscina.

(Chancel.) The windows, north and south, are Early English, and the Hagioscope appears to have been formed during that period. The bottom is boarded with oak. There appears to have been a plinth to the piers of the chancel arch; but, as the pewing blocks it up, I cannot discover any more than what is shown on the plan. The chancel has a flat boarded ceiling; between the chancel and nave there is a Jacobean Screen, which presents some good points in its design and character.

The Perpendicular Screen is rather elaborately coloured; the panels are painted red, with fleur-de-lis in white upon it; the heads of the tracery are painted blue, the fillet of the moulding is green, and the hollow white.

(Nave.) In the north-east angle of the nave is a large pew, with a canopy of the same date, or rather later, than the James I. screen. On the north side of the nave, $5 \mathrm{ft} .6 \mathrm{in}$. westward of the chancel arch, is a niche with a flat Tudorarched head, $4 \frac{1}{9}$ in. deep, $2 \mathrm{ft}$. $3 \frac{1}{9}$ in. wide, $2 \mathrm{ft}$. 6 in. to springing, and the bottom of the niche is $6 \mathrm{ft} .4 \mathrm{in}$. from the ground.

Immediately under the window, on the north side of nave, is an arched recess, $2 \mathrm{ft} .1 \frac{1}{2} \mathrm{in}$. from the ground.

The Pewing consists of the old seats cased with deal. The old open seats are, I think, late Decorated. The roof is waggon-headed, with spandril pieces, supported by angels bearing shields; the wall-plate is embattled.

(Tower.) The walls of the belfry stage, internally, are built of rubble-work composed of flint and freestone. There are three bells, one with "Anno Domini 1618," in black letter ; the second is inscribed with the date, "Anno Domini 1579 ;" and the third has the inscription, "Sancta Trinitas Salva Me," in Church text. From the belfry stage, downward, the tower is of coursed flintwork on the internal face, and the jambs of the windows in that stage are finished with rough-cast, flush with the stone dressings; and the soffits of 
the heads are finished with a series of channels in the roughcast, radiating as arch-stones.

(Nave.) West of tower, the roof is of the same kind as the other part of nave, but not ceiled to underside of collar and strut. The Font is octagonal. The door on the south side is late Decorated, or Perpendicular. There is a perpendicular two-light window over west doorway.

(Exterior.) The Tower is covered with rough-cast, worked up to and flush with the free-stone.

On the North side, the belfry opening is shown in the representation here given. The large arch has twenty-two pellets, on the outer ring; there are twenty compartments in the second division, and nineteen double cones in the third. The west side arch is the same as those on the east face.

On the East face, the large arch is divided into two; the outer ring has billets semicircular in section, and on the inner is a chevron; the inner arch has a bead on the edge, and the side arches are shown together with the others, in the accompanying representation.

On the South face, the large arch has mouldings; the inner arch is perfectly plain; and the side arches are the same as the east one on the north face.

The bell-gable, for the Sanctus bell, is built of a yellow coloured brick, very much the same as a clinker. The soffit is of wood supporting the pyramidical top. The roof, east of tower, is of thatch, pitched; that to the west, of tiles. The walls, externally, consist of flint rubble-work, covered with rough-cast and whitewash.

The Central Commitres have the gratification again to express their acknowledgment and cordial thanks for most valuable assistance and encouragement shown, on so many occasions, by Mr. PetrT. The Members of the Institute will gratefully esteem the generosity by which a highly valuable Monograph has been here presented to them. The drawings and numerous engravings, which display the instructive features of one of the most characteristic examples of its period, in East Anglia, have been liberally presented to the Institute by Mr. PeTrT. 